\title{
The Moderating Effect of the Presence of Female Executives on the Relationship Between Accounting Conservatism and Cash Holdings
}

\author{
Souad Chaieb \\ $\mathrm{PhD}$ in Accounting, Laboratory of Governance Finance Accounting \\ Faculty of Economics and Management, University of Sfax, Tunisia \\ Tel: 216-2729-2970Ｅ-mail: chaiebsouad1@gmail.com
}

Received: July 11, 2021

Accepted: July 31, 2021

Published: August 30, 2021

doi: 10.5296/ijafr.v11i3.18850
URL: https://doi.org/10.5296/ijafr.v11i3.18850

\begin{abstract}
This paper aims to providing evidence for a relationship that could be established between accounting conservatism and cash holdings and to integrating the moderating effect of the presence of women directors on this relationship. The study was carried out on a sample of 100 French companies listed in the SBF120 index over a 5 year period. In general, the results show that the effect of accounting conservatism on the holding of liquidity is positive and significant and that the role of female administrators reinforces this relationship.
\end{abstract}

Keywords: Accounting conservatism, Cash holdings, Female leadership

\section{Introduction}

The issue of the importance of liquidity would not arise in a perfect world because in that universe, companies that need liquidity to finance their investments or to meet obligations will be able to free up external funds on the capital markets (Brown and Petersen, 2011). In a world of unstable economy, firms are forced to maintain a certain level of liquidity that is not random to respond to their needs. Several theories propose an explanation to this need for liquidity. The most well-known of such theories is undoubtedly that proposed by Keynes (1936).

Since 1936, Keynes went against the idea of not having any cash, attaching this obligation to commercial psychological factors. As a result, Keynes (1936) provides an explanation for this need by referring it to four factors in order to explain the need for liquidity holding. These are the need for transaction, preventive custody as a precaution, holding by speculation and the need for financing. 


\section{Mll Macrothink}

International Journal of Accounting and Financial Reporting

ISSN 2162-3082

2021, Vol. 11, No. 3

The field of research concerning cash holdings, has received little interest from the researchers of the financial theory. However, the main work on this subject in the late 1990s focused on the analysis of managerial practices. It is not surprising that the issue of cash holdings was addressed by Morris (1983), and that the cash holdings was deemed by Brealey and Myers (2006) as one of the major ten undetermined problems in the company's finance.

The development of research on this concept has not received an increasing interest until the year 2000 by several researchers including Ogundipe et al. (2012); Tahir and Alifiah (2015) and Bruce and Halit (2016).

However, there is still no consensus on the relationship between cash holdings and other financial or accounting concepts. Therefore, the corporate liquidity holdings forms a field of investigation that has animated the theoretical debate but also the empirical debate that remains unsolved due to the fact that the justifications found are questionable.

In this study, emphasis will be put on the potential relationship between the concept of cash holdings and that of accounting conservatism while considering the presence of female administrators.

Based on the work of Basu (1997), accounting conservatism could be defined as a fundamental principle of accounting that has important economic results. In fact, accounting conservatism effectively influences problems of moral hazard between managers, creditors and shareholders. It also helps to reduce information asymmetry and protects shareholders' interests by serving as governance mechanisms to limit managerial opportunism.

Nevertheless, several studies have focused on the relationship between governance mechanisms and the nature of accounting information. These results show that generally, governance mechanisms related to the audit quality, the quality of the composition of the administration board and that of the financial report are directly associated with the quality of information (Klein, 2002) ; (Doyle et al.2007).

The objective of this study is in continuity with the line of thought of this theoretical logic. It aims to show the importance of the quality of accounting information, and presents it as a reduction of information asymmetry that would have favourable effects on increased liquidity.

According to (Kothari et al. 2009) a weak information asymmetry could produce more stable and less volatile yields in addition to bringing more accuracy to managers' forecasts. The hierarchical financing theory seeks to analyse the notion of ownership based on information asymmetry, because of which external financing methods are more expensive. For this reason, companies opt for cash holdings to finance their investments at a lower cost in order to minimize the transaction costs of external financing.

On the other hand, the management of accounting results is one of the causes of disruption of the studies on the quality of accounting information, as it questions the quality of financial statements. Other causes of disruption of the studies on the quality of accounting information include the Accruals approach of (Jones1991). The Accruals model is very useful, for it has 


\section{Ml Macrothink}

International Journal of Accounting and Financial Reporting

ISSN 2162-3082

2021, Vol. 11, No. 3

been presented in the literature as the most appropriate measure of information quality (Dechow et al. 2010), since accounting conservatism, significantly influences accounting practices. Additionally, it is defined as the ability of accountants to opt for a low or high degree of control in order to identify the accuracy of information likely to lead to gains or losses (Basu 1997).

In practice, this ability certainly affects accounting results. As Basu (1997) predicts, analyses of the results lead to identifying bad before good news. This could be explained by the fact that the company receives news of bad news during the current accounting period, and the sum of data will be identified then sent back during the same accounting period. This is mainly due to a fast knowledge of bad news in the context of accounting conservatism. This result is followed by the creation of a link between the results of the accounting practices and the bad news.

However, several interpretations were developed by researchers in order to explain the tendency of conservative accounting practices. Moreover, Watts (2003) believes that accounting conservatism has implications for normalizer decisions on accounting standards to demonstrate consideration of a precautionary level in the accelerated recognition of losses and delayed recognition of gains. Similarly, Zarai and Adberrahim (2009) estimate that the accounting for depreciation is an expense for the period that is only a practice designed to reduce income tax.

It is also important to mention that the managers' decision to adopt conservative practices allows cost maintenance and the monitoring of the companies' mechanisms. Management mechanism is thus presented as a result that can provide accurate and net information on the financial statements. Financial information has the purpose of meeting the needs of creditors and shareholders. On the other hand, contractual relations have a great influence on how to manage accounting results. Similarly, applying conservative measures can be justified by the contractual reports between a company and its partners or between both. In fact, Jensen and Meckling's (1976) agency theory considers the firm as a node of contracts involving multiple economic agents, as each agent seeks to satisfy its own needs, which gives rise to conflicts at the level of the first axis of relations between the managers and the shareholders, and in a second axis between the shareholders and the creditors.

Our hypothesis is in the same line of thought as Watts (2003) which maintains that the conservative accounting practices can reduce agency problems in general. Besides, accounting conservatism can also promote the effectiveness of investment policies, as it contributes to mitigating the underinvestment in capital rationing and limits over-investment by forcing managers to recognize losses quickly. More importantly, accounting conservatism can lead to more efficient investment decisions, facilitate the monitoring of managers' investment decisions and therefore mitigate the value destruction associated with cash holdings.

The financial literature refers to a gender language in the corporate governance code; Adams and Ferreira (2009) show that the presence of women influences the dynamics of the administrative board. This has a significant impact on business decisions and results and 
reinforces surveillance efforts, which ultimately improves business strategic decisions. Similarly, Gul et al. (2011) suggest that decisions made by a board composed of members of both genders complement corporate governance and good management practice. In the same context, the presence of women in making administrative decision has a positive impact on the value of an enterprise (Campbell and Minguez Vera 2010). Moreover, women CEOs prefer to avoid risky financing and investment opportunities (Adhikari et al. (2016), Zeng and Wang (2015) as their decisions are more rational and risk-averse.

According to Schrandet Zechman (2011), women CEOs' conservatism and ethical convictions can serve as a natural defense against fraud and, consequently, have more important accounting and economic implications, and this would contribute to an increase in cash holdings. Sanyum and Lihong (2015) show that female CEOs are much more conservative and associated with a much higher level of cash in companies compared to their male counterparts.

In this study, we seek to understand the effect of accounting conservatism on cash holdings and evaluate the role of women's in order to understand the importance of their presence on the board and whether they have moderated this relationship.

The rest of this article will be structured as follows: the section entitled "Literature Review and the development of hypotheses" presents a theoretical basis to explain the relation between accounting conservatism, cash holdings and female leadership. The section called "Data and Methodology" will focus on statistics and research methodology while referring to the selected sample, the measurement of the different variables and the different statistics. The "Results" section discusses the empirical results and their interpretations, and the conclusion gathers some remarks while suggesting future lines of research on the treated subject.

\section{Literature Review and Development of Hypotheses}

\subsection{The Effect of Accounting Conservatism on Cash Holding}

Empirical studies focusing on accounting conservatism are numerous. Some are centered around the evolution of conservatism practices throughout time (Givoly and Hayn, 2000; Holthausen and Watts, 2001; Sivakumar and Waymire, 2003; Raonic et al. 2004). Some focused on the variability of conservatism between the different quarters (Basu et al. 2001), and still others on the divergence of conservative practices between legal regimes and countries (Huijgen and Lubberink, 2005; Ball et al. 2008). Others also focused on the association between conservatism and some company governance mechanisms (Garcia et al. 2009; Ahmed and Henry, 2012), or on the distinction of conservatism between firms or sectors of activity (Basu, 1997; Ball and Shivakumar, 2005; Kwon et al.2006), the adoption of the international reference system with the evolution of accounting conservatism (Hung and Subramanyam, 2007; Garcia et al.2008; Kaytmaz et al. 2010; Piot et al.2011; André and Filip, 2011; Ahmed, Neel and Wang, 2013), and on the link between the cost of debt and accounting conservatism (Zarai and Abderrahim, 2009) and so on. 
In the following part, several empirical studies by the aforementioned researchers will be cited in order to show the existing relationship between accounting conservatism and cash holdings. In other words, this study will focus mainly on proving the importance of the impact of accounting conservatism on reducing conflicts of interests between shareholders and managers, which would consequently mitigate the value destruction associated with cash holdings.

Several studies show that the quality of accounting information is positively associated to favorable economic consequences such as reducing the cost of capital (Francis et al. 2004; Daske 2006 and Li 2010), increasing liquidity of securities (Daske et al. 2008) and introducing more effective investment policies, which are explained by a reduction in overor under-investment (Biddle et al. 2009; Garcia Larra et al. 2016).

A better accounting information, as it reduces information asymmetry (Leuz and Verrecchia 2000; Bushman and Smith 2001), is therefore likely to promote the effectiveness of investment policies (Biddle and Hilary 2006, Biddle et al. 2009).

Conservatism is referred to as a dimension of the quality of accounting information. In fact, according to (Watts 2003), accounting conservatism is an effective governance mechanism as it secures the response to the moral hazard due in particular to the information asymmetry between the different stakeholders of a given society. Indeed, accounting conservatism checks managers' opportunist behavior and reduces their capacity to overestimate profits and assets. Chen et al. (2011) examine the relationship between the quality of accounting information and the effectiveness of investment choices through examples of companies not owned in emerging countries. The writers prove that even for these companies, the quality of accounting information has a positive impact on the effectiveness of investment policies.

Moreover, previous studies show that accounting conservatism plays an important role in mitigating information asymmetry and limits the gap between initiates and non-initiates in terms of lower agency costs. The major tenets of this theory according to the work of (Jensen and Meckling 1976) show that the initiates have more information, are more motivated to be positively bias regarding the information they provide foreigners with and take measures resulting in losses.

Watts (2003) and Holthausen and Watts (2001) argue in fafor of the important role of conservatism in solving agency problems. Francis and Martin (2010) also describe a positive association between accounting conservatism and the profitability of investments, mainly among enterprises with higher ex ante agency costs. Hu et al. (2014) indicate in their study the existence of positive link emanating from accounting conservatism and improving the company's information environment. They also indicate that the presence of accounting conservatism is higher in companies that have good corporate governance mechanisms.

Lafond and Roychowdhury (2008) and Cullinan et al. (2012) find that accounting conservatism is negatively associated with property manager. In fact, a study conducted in the United States found that companies with effective governance structures practice higher levels of accounting conservatism (Leventis et al. 2013). Dechow et al. (2010) also show that 
the quality of accounting information improves the effectiveness of companies' investment policies.

More precisely, a company could be conceptually considered as investing effectively if it undertakes projects with a positive net present value (NPV). Over-investment thus consists in investing in projects with a negative NPV, while under-investment can be defined as not investing in projects with a positive NPV. Financial theory stipulates that there is an optimal level of investment and that companies are likely to move away from it by over or under investment due in particular to the existence of frictions in financial markets. These frictions in particular are moral hazard and adverse selection. They result from the information asymmetry between managers and external capital providers.

The models that elaborate on the issue of moral hazard are based on the idea that the managers whose purpose is to maximize their personal profit usually carry out investment that are not in the interest of shareholders. These models suggest that when the interests of managers and shareholders are conflicting, managers are likely to invest in negative net present value projects. Accounting conservatism also plays a governance role in monitoring corporate investment decisions. By recognizing economic (or projected) losses earlier, conservatism helps to identify negative NPV projects or underperforming investments, therefore improving investment efficiency (Bushman et al. 2011).

In the case of excess capital, moral hazard leads to over-investment situations, such as the use of benefits in kind or the expansion of the company beyond its optimal size (Jensen 1986). Nevertheless, providers of capital are likely to take these situations into account and, consequently, ration "ex ante" capital, which may lead to "ex post" underinvestment.

Models elaborating on the issue of adverse selection suggest that if managers are essentially more informed than investors about the company's perspectives, they will thus seek to plan capital issues to sell shares at an overvalued price. If they do, then they are likely to invest the excess funds obtained (over-investment). However, investors can rationally respond to this eventuality by rationing capital, which translates into ex-post underinvestment.

Information asymmetry between managers and capital providers, which results in conflicts such as problems of moral hazard or adverse selection, thus limits the effectiveness of investment policies (by generating over- or under-investment behaviour). Managers can use their financial information discretion in order to conceal losses. Nevertheless, companies with a conservative financial reporting culture and policies are more likely to report losses on new projects in a timely manner than those with a less conservative financial reporting culture and policies.

As indicated by Skinner (1993), in order to maximize the value of their companies, managers can voluntarily commit to conservative accounting procedures. These procedures are determined by contractual parties and applied by external auditors. Many studies show that conservative accounting choices within companies tend to be fairly stable over time (Khan and Watts 2009, Callen et al. 2010). 


\section{$\Lambda$ Macrothink}

International Journal of Accounting and Financial Reporting

ISSN 2162-3082

2021, Vol. 11, No. 3

As a consequence, companies do not directly change their post-investment reporting policies. Generally, conservative companies continue to prudently report after investments, as accounting conservatism implies a rapid identification of losses and a late recognition of capital gains. It can also lead to under-investment.

In a context where under-investment represents an issue, accounting conservatism could have a negative effect by exacerbating the problem of underinvestment. However, the observed reduction in liquidity is generally linked to over-investment, and more precisely to managers' tendency to engage in projects with negative NVP (Jensen, 1986; Faulkender and Wang, 2006; Dittmar and Mahrt- Smith 2007).

This observation is in line with Jensen's (1986) free cash flow hypothesis. He suggests that when a conflict of interest between shareholders and managers takes place, managers become more opportunistic and would likely accumulate excess liquidity to serve their own interests, which are at odds with the interests of shareholders.

For opportunistic leaders, their favorable choice is the liquidity reserve, as it gives them the financial flexibility they need to take root and exempt themselves from the control of shareholders and creditors. This opportunistic behavior can lead to an exaggerated diversification and over-investment. Indeed, the shareholders who effectively control the leaders' work are not in a working environment of fear in the face of opportunistic or sub-optimal liquidity attitudes. As a result, they are able to allow executives to accumulate more liquidity to avoid a problem related to underinvestment (La Porta, et al. 2000).

Generally, the use of conservative accounting information in contracts (especially compensation and debt contracts) encourages managers to skew these data (Watts, 2003; Ball et al. 2008).Nevertheless, it is not difficult to understand that company leaders have stronger incentives to be optimistic or to publish good news, which can have a positive impact on the amount of their remuneration or on the evaluation of compliance with restrictive borrowing clauses, rather than bad news (such as investment projects with a negative NPV).

In the absence of constraints on opportunistc behavior, accounting measures are likely to be significantly biased, and it becomes then difficult for capital providers to properly control leaders. Conservatism thus allows a better control of the leaders by the contributors of capital, which will initially weaken the problem of capital rationing and thus reduce under-investment.

Conservatism implies the rapid recording of losses. This timely process is necessary, as it allows identifying the effects of the managers' actions on the value of the firm in the period in which these actions are carried out.

Ball and Shivakumar (2005) show that accounting conservatism de-motivates managers to invest in projects having a negative NVP or in low-performing investments because they cannot delay accounting for future losses.

Habib and Hossain (2013) show that in Australia, accounting conservatism positively affects a company's leverage structure. 
Biddle and Hilary (2006); Biddle et al. (2009) hypothesize that higher quality accounting information is associated with no less sensitivity of the investment to cash flows, which may be either a deficit or an excess of cash, but less under-investment or over-investment, or both at once. Their research results prove that a high quality accounting information is associated not only to a weaker under-investment, but also to a weaker over-investment.

The study conducted by Garcia Lara et al. (2016) is the only to focus on the relation between conservatism and over- or under-investment. The research results show that for a sample of American companies, a higher level of conservatism as defined by Basu (1997) can be explained by a probability of over- or under-investing.

Bushman et al. (2011) show that the rapid identification of economic losses increases the sensitivity of business investment to the decline of international investment opportunities.

Therefore, building upon what is mentioned above, it goes without saying that conservative accounting practices can alleviate agency problems in general. Additionally, accounting conservatism is likely to improve the effectiveness of investment policies in addition to mitigating the sub-investment tied to capital rationing and limiting over-investment by forcing managers to quickly recognize losses.

More precisely, accounting conservatism can contribute to formulating efficient investment decisions and facilitating decision-making by managers, and therefore mitigate the value destruction associated with cash holdings.

Thus, the first hypothesis can formulated be as follows:

\section{H1: There is a positive relationship between accounting conservatism and cash holdings.}

\subsection{The Effects of the Presence of Female Administrators on the Relationship Between Accounting Conservatism and the Cash Holdings}

The socio-cultural model considers gender differences in personality to be directly caused by social and cultural factors such as social roles and gender stereotypes (for example, male assertiveness and female fear). The bio-social model indicates that gender differences have both biological and sociocultural causes. The literature on psychology (Costa et al. 2001) considers that women are less authoritarian and less aggressive. Simon et al. (2014) indicate that women are more anxious than men. Generalized anxiety disorder and depression are more widely diagnosed in women than in men.

Niederle and Vesterlund (2007); O'Laughlin and Brubaker (1998) found that women are less confident than men. They also found that women are less likely to take part in risky behaviours such as gambling (Levin et al. 1988). In an experimental study, Powell and Ansic (1997) found that women opt for less risky alternatives. Byrnes et al. (1999) predict that the risk is significantly lower for women than for men, as women are more fearful of failure when they decide to become independent (Wagner, 2007). Huang and Kisgen (2013); Faccio et al.(2016), Adhikari et al. (2016), Zeng and Wang (2015) note that female executives are less overestimated in making financial decisions than their male counterparts. 


\section{MInstitute ${ }^{\text {Macrothink }}$}

International Journal of Accounting and Financial Reporting

ISSN 2162-3082

2021, Vol. 11, No. 3

Besides, female CEOs prefer to avoid risky financing and investment opportunities. Companies with female CEOs have a lower leverage effect, less volatile profits and a greater chance of survival than companies that are composed mainly of male CEOs (Faccio et al. 2016). Similarly, Mateos de Cabo et al. (2012) believe that low-risk banks are associated with a higher proportion of female directors, which could be explained, among other things, by an assumption of risk aversion. Additionally, women tend to perceive risks as greater, adopt less risky behaviours and choose more thoughtful alternatives (Eckel and Grossman 2008, Jianakoplos and Bernasek 2007).

In addition, a stronger ethical disposition was observed among women in the accounting context. They are generally described as less authoritarian, less aggressive, too insecure, more concerned, more risk-averse, and more ethical. All of these qualities suggest a conservative mindset and a weak willingness to fraud (Vermeir and Vankenhove 2008).

According to Ibrahim and Angelidis (2009), female professional accountants consider ethics to be a more important factor in recruiting junior public accountants than their male counterparts. Fraudulent companies have a significantly lower number of female directors than non-fraudulent ones. This demonstrates that women are more sensitive to ethics and less likely to be fraudent (Cumming et al. 2014).

This stronger ethical disposition of female leaders leads to stronger ethical leadership, and thus a more ethical work environment. This work environment promotes honesty in financial reporting and potentially promotes more conservative accounting. As a result, the conservative mindset and ethical leadership of female CEOs could contribute to a better internal control environment with a stronger focus on conservative financial reporting. Consequently, the conservative mindset of female CEOs and their firm opposition to fraud should enforce the presence of conservatism in accounting.

According to Schrand and Zechman (2012), the conservatism and ethical convictions of female CEOs can serve as a natural defense against fraud and, therefore, have more significant accounting and economic implications. Francis et al. (2014) examine the association between CEO gender diversity and accounting conservatism, and find that the financial reporting of female $\mathrm{CEO}$ is more conservative.

According to Simon et al. (2014) and given the conservative mentality and ethical values of female CEOs, it is noted that there is a positive association between the presence of a female CEOs and accounting conservatism. Moreover, the study shows that female CEOs who are generally more cautious about taking risks, will be even more cautious in their financial reporting when the company faces a higher risk of litigation and takeover. Huang and Kisgen (2013) note that female executives issue much wider earnings ranges than their male counterparts. This shows that female executives are conservative in accounting duties. According to Francis et al. (2013), banks are aware of the better quality, conservative and reliable revenues reported by CEOs, and, consequently, they are more likely to deal with companies with female CEOs through more favorable contractual terms. 


\section{Mll Macrothink}

International Journal of Accounting and Financial Reporting ISSN 2162-3082 2021, Vol. 11, No. 3

Krishnan and Parsons (2008) noted a higher profitability for companies hiring more female executives. Therefore, female leaders bring economic value to companies, since more rigorous ethical leadership is often seen as the key to organizational success and the guarantee of increased profitability, performance (Prottas, 2013), employee satisfaction and professional engagement (Brown and Mitchell, 2010; Hunter, 2012; Neubert et al.2009). Female CEOs cherish the work environment and give more importance to equal pay for workers including the newly hired (Tate and Yang, 2015).

Rodriguez et al. (2012) observe a stronger performance of women compared with men in working conditions and recommend a greater representation and presence of women in administrative boards. Evershed LLP (2011) shows that companies hiring more women in positions of responsibility suffer less in periods of economic slowdown, which suggests that gender diversity significantly contributes to sustainability.

Women directors influence the dynamics of the administrative board and act differently from their male counterparts. This has a considerable impact on the board's decisions and the firms' performance and reinforces surveillance efforts (Adams and Ferreira 2009). According to Arfken et al. (2004), women directors' points of view and ideas are exceptional resources, and the membership of women directors on boards improves the strategic decisions of companies. Gul et al. (2011) suggest that joint boards improve corporate governance.

Kotiranta et al. (2007) report that enterprises led by women made higher profits, which reflects perhaps women's contribution to global cultural diversity and multi-dimensionality in businesses, and the application of good governance and management practices.

Francoeur et al. (2008) note that companies operating in complex activities generate positive and significant abnormal returns when they have a high number of female CEOs. Similarly, the presence of women on boards brings a positive effect on the value of the enterprise (Campbell and Miguuez-Vera 2008). Investors consider hiring women as an added value, and stock markets respond positively to these announcements (Campbell and Minguez Vera 2010).

Luckerath-Rovers (2010) observes that out of a sample of 99 Dutch firms, those with female managers performed better. Studies indicate that correcting the gender imbalance in enterprise leadership results in high marginal benefits. Another study by Xi el al. (2019) that is based on a sample of Chinese listed companies between 2007 and 2015 shows that companies with female CEOs hold much more liquidity, which is in favor of the explanation based on precautionary savings. Additionally, Adhikari (2018) found that women- led enterprises hold much more liquidity for precautionary reasons and that the sum of findings are in line with the idea that more risk aversion leads women executives to retain more liquidity.

Sanyum and Wang (2015) empirically investigate how the gender of the executive officer affects corporate cash and over-investment in free cash flows based on a sample composed of publicly traded Chinese companies. The study was based on a sample of 468 publicly traded companies with female CEOs and a matched sample of companies with male CEOs in the 


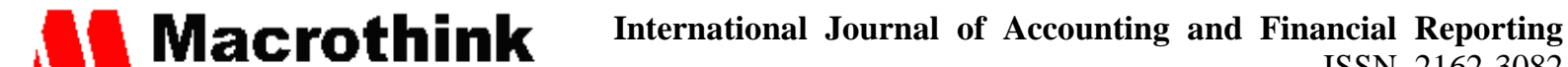 Institute"'

period of 2007-2011. The empirical results show that CEO women are associated with a higher level of corporate cash holding. Compared to their male counterparts, women CEOs are more concerned about the precautionary motive of cash, while they are less concerned about the opportunity cost of cash. Moreover, the study shows that female CEOs moderate the problem of over-investment related to free cash flows, thereby also indicating that they are more conservative than their male counterparts.

These observations suggest a significantly positive association between the relationship of accounting conservatism and cash holdings. On the other hand, female leadership influences accounting conservatism and predicts that decisions made will be more rational and risk-averse, thereby resulting in an increase in cash holdings.

This implies that one can propose the following hypothesis:

H2: The presence of female executives moderates the relationship between accounting conservatism and cash holdings.

\section{Methodology}

\subsection{Sample Definition and Description of Variables}

\subsubsection{Sample Definition}

The sample for this study consists of the recurring SBF120 population over five successive years. However, some restatements were necessary in order to exclude: Companies that were subject to merger and acquisition transactions throughout the duration of the study; banks and insurance companies because they are subject to specific regulations; companies whose annual reports were not available on the Internet; companies with partially incomplete reports or data or whose accounts have not been completed by 31 December.

The SBF 120 index includes the 120 companies listed in France with the highest market capitalisation. The choice of a stock exchange index makes having a homogeneous population over the reference period possible. Additionally, the interest in conducting a study on companies that are part of a stock index was motivated by the availability of information.

The final sample is composed of 100 companies. This research was thus conducted on 100 companies with a $120 \mathrm{SBF}$ index between 2011 and 2015. There are, therefore, 500 observations in our disposition, and these represent 100 companies. Data were collected based on corporate annual reports and reference documents. These documents are available on the companies' websites.

\subsubsection{Presentation of Variables}

\section{- Description of Dependent Variable Measurement:}

The variable of Cash Holdings (CASH) will be explained and supported based on the measures developed by Opler et al. (1999). This variable is calculated by dividing the value of liquid assets (investment securities + availabilities) by the total balance sheet amount once the amount of liquid assets is deducted. 


$$
\mathrm{CASH}=\frac{\text { liquid assets }}{\text { total assets }- \text { liquid assets }}
$$

However, this measure fails to formulate extreme values for companies holding a large part of their assets in cash. This is why we selected the most common formula which is calculated by selecting the amount of liquid assets (cash and cash equivalents) divided by the total assets. The CASH variable is thus defined as the ratio between the value of liquid assets and the total assets of the company (Opler et al., 1999; Zeljko et al., 2017).

$$
\mathrm{CASH}=\frac{\text { cash and cash equivalents }}{\text { total assets }}
$$

\section{- Description of Independent Variable Measurement:}

In order to assess the degree of conservatism practiced by French firms, this study refers to the model of Ball and Shivakumar (2005), the model of Ball et al. (2008) and the recent model of Simon et al. (2014) where accounting conservatism by accruals is measured(Dechow et al 2010).

In order to maintain the negative value of accruals, we add to our different models to be tested a DACC*ACC interaction variable, as ACC represents the increased discretionary values (total accruals):

$$
\mathrm{ACC}=\frac{\text { Net income-operating cash flow }}{\text { total assets }}
$$

DACC indicates a binary variable equal to one if ACC is negative, and zero if ACC is positive. This negative measure of accounting conservatism is in line with several previous studies that support the assumption that accounting accruals are generally conservative in nature (Ball and Shivakumar 2005; Basu 1997; Givoly and Hayn 2000).

If the coefficient of the interaction variable DACC* $|\mathrm{ACC}|$ is positive and statistically significant, this indicates that accounting conservatism affects the level of cash holdings.

\section{-Description of Moderating Variable Measures:}

A moderating variable is determined as a variable that specifically acts on the association between two other variables. It systematically changes the inten<sity, magnitude, meaning or/and shape of the impact of the independent variable on the dependent variable (Sharma et al., 1981).

Among the hypotheses advanced in this research, we highlight that which supports a moderating role in the context of the main studied relation. In other words, we will seek to prove whether the impact of accounting conservatism on the company's cash holdings level is affected by the presence of female executives.

In this study, the variable of the presence of female executives is defined as the percentage of female members of the company's board of directors. This measure of gender diversity as a 
proportion of board members reflects the influence of female directors as Mahadeo et al. (2012) demonstrate.

\section{-Description of Control Variables:}

These variables can have a significant effect on dependent variables. We note the size of the enterprise (SIZE) and economic profitability (ROA).

\section{Firm Size:}

The firm size also represents a major variable in order to explain corporate performance. This factor has been tackled by several studies as a variable with direct and indirect consequences on the cash holdings.

Several measures were taken to evaluate the firm size. Bahagat et al (2001), Durnev and Kim (2005), Andres et al. (2005) use the "log (sales)" measure. Other authors, such as Bauer et al. (2008), Adjaoud et al. (2007) use "log (total assets)".

We use the following measure:

$$
\mathrm{SIZE}=\log \text { (accounting value of total assets) }
$$

\section{Return on Assets (ROA):}

The ROA variable is used in works to refer to corporate financial performance. This variable presents the profitability of the capital invested and explains the ability of this capital to generate such a level of operational gains. This measure was applied by a majority of authors like Daines (2004), Adams and Santos (2006).

In our study, we will use the following measure to calculate ROA:

$$
\mathrm{ROA}=\text { Net income } / \text { Total assets }
$$

Table 1. Summary of different variables

\begin{tabular}{clllc}
\hline & variables & \multicolumn{1}{c}{ Required data } & References & $\begin{array}{c}\text { Sources of } \\
\text { information }\end{array}$ \\
\hline $\begin{array}{c}\text { Dependant } \\
\text { Variable }\end{array}$ & Cash holdings & $\begin{array}{l}\text { CASH : cash and cash } \\
\text { equivalents / total } \\
\text { assets }\end{array}$ & $\begin{array}{c}\text { Opler et al. } \\
(1999), \text { Zeljko } \\
\text { et al. (2017) }\end{array}$ & $\begin{array}{c}\text { Annual } \\
\text { Reports }\end{array}$ \\
\hline $\begin{array}{c}\text { Independant } \\
\text { Variable }\end{array}$ & $\begin{array}{c}\text { Accounting } \\
\text { conservatism }\end{array}$ & DACC*|ACC| & with: & Simon et \\
& & -ACC: (net income - & Annual \\
& & operating cash & Reports \\
\hline
\end{tabular}


flow)/total assets

-DACC: binary

variable equal to 1 if

$\mathrm{ACC}$ is negative, and

0 if ACC is positive.

\begin{tabular}{|c|c|c|c|c|}
\hline \multirow{2}{*}{$\begin{array}{l}\text { Moderating } \\
\text { Variable }\end{array}$} & & & & \\
\hline & $\begin{array}{l}\text { Presence of } \\
\text { female } \\
\text { administrators }\end{array}$ & $\begin{array}{l}\text { PFAD: percentage of } \\
\text { female executives }\end{array}$ & $\begin{array}{l}\text { Mahadeo et al. } \\
\text { (2012) }\end{array}$ & $\begin{array}{l}\text { Annual } \\
\text { Reports }\end{array}$ \\
\hline \multirow[t]{2}{*}{$\begin{array}{c}\text { control } \\
\text { Variables }\end{array}$} & Firm size & $\begin{array}{l}\text { SIZE: logarithm of } \\
\text { total assets }\end{array}$ & $\begin{array}{l}\text { Bauer et al. } \\
\text { (2008) }\end{array}$ & $\begin{array}{l}\text { Annual } \\
\text { Reports }\end{array}$ \\
\hline & Return on assets & $\begin{array}{l}\text { ROA : net income } \\
\text { /total assets }\end{array}$ & $\begin{array}{c}\text { Adams and } \\
\text { Santos (2006) }\end{array}$ & $\begin{array}{l}\text { Annual } \\
\text { Reports }\end{array}$ \\
\hline
\end{tabular}

\subsection{Statistical Methods}

\subsubsection{Presentation of the Model}

During our analysis, a statistical method will be used through the Stata software. The latter is the multiple linear regressions on panel data which is written as follows:

$$
\begin{aligned}
& \text { CASH it }=\beta_{0}+\beta_{1} \text { DACC it }+\beta_{2} \text { ACC it }+\beta_{3} \text { DACC } * \text { ACC it }+\beta_{4} \text { PFAD it }+\beta_{5} \text { DACC } * \text { PFAD } \\
& \text { it }+\beta_{6} \text { ACC } * \text { PFAD it }+\beta_{7} \text { DACC } * \text { ACC } * \text { PFAD it }+\beta_{8} \text { SIZE it }+\beta_{9} \text { ROA it }+\varepsilon i t(1)
\end{aligned}
$$

With:

$\mathrm{CASH}_{\mathrm{it}}=$ cash holding (cash and cash equivalents / total assets).

$\mathrm{ACC}_{\mathrm{it}}=$ discretionary accruals ((net income - operating cash flow)/total assets).

$\mathrm{DACC}_{\mathrm{it}}=$ binary variable equal to 1 if $\mathrm{ACC}$ is negative, and 0 if $\mathrm{ACC}$ is positive.

DACC* $\mathrm{ACC}_{\mathrm{it}}=$ is an interaction variable between the discretionary accruals variable and the discretionary accruals binary variable. This is the variable that measures accounting conservatism.

$\mathrm{PFAD}_{\mathrm{it}}=$ percentage of female executives

DACC $* \mathrm{PFAD}_{\mathrm{it}}=$ this is an interaction variable between the binary variable of discretionary accruals (DACC) and the percentage of female executives (PFAD).

$\mathrm{ACC}^{*} \mathrm{PFAD}_{\mathrm{it}}=$ this is an interaction variable between the accruals discretionary variable (ACC) and the percentage of female executives (PFAD).

$\mathrm{DACC}^{*} \mathrm{ACC}^{*} \mathrm{PFAD}_{\mathrm{it}}=$ this is an interaction variable between the discretionary accruals variable, the discretionary accruals binary variable and the female executive variable

$\mathrm{SIZE}_{\mathrm{it}}=$ firm size (logarithm of total assets) 


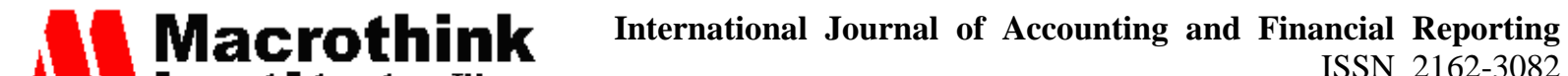

$\mathrm{ROA}_{\mathrm{it}}=$ return on assets (Net income / total assets)

$\varepsilon_{\mathrm{it}}=$ the error term of this model.

\subsubsection{Specification Tests}

\section{- Verification of the Condition of the Absence of Multicollinearity:}

Pearson's correlation matrix specifically examines the absence of complication of multicollinemarity in explanatory variables where independent variables may lead to risks such as low accuracy and the appearance of robust regression coefficients.

According to Groebner et al. (2008), the existence of such a problem in the model can generate incorrect signs and coefficients and thus distort the results and conclusions of the analysis.

After applying the VIF test to the variables selected in the model, we observe that no correlation coefficient was able to reach the threshold set at ten which triggers the dominance of collinearity risks.

In fact, the Variance Inflation Factor (VIF) test showed that the highest value is barely 1.22. This result is well below the threshold of 10 .

\section{- Hausman Test:}

The Hausman specification test (1978) allows to measure the existence of well-determined individual effects in order to determine the existence of fixed or random effects.

By applying this test, we noted that the $\mathrm{p}$ - value is higher than 5\%. This leads us to opt for variable effect models (Random Effect).

\section{Results}

\subsection{Descriptive Statistics of Variables}

Our sample is composed of 100 companies. The different variables adopted in the econometric model as well as the descriptive statistics are mentioned in the following table:

Table 2. Descriptive statistics

\begin{tabular}{llllll}
\hline Variable $^{\mathrm{a}}$ & Obs & Mean & Std.Dev. & Min & Max \\
\hline CASH & 500 & 0.119 & 0.181 & 0.001 & 1.960 \\
ACC & 500 & 0.043 & 0.024 & 0.010 & 0.099 \\
DACC & 500 & 0.856 & 0.351 & 0 & 1 \\
PFAD & 500 & 0.268 & 0.099 & 0 & 0.54 \\
SIZE & 500 & 4.040 & 0.684 & 2.022 & 6.898 \\
ROA & 500 & 0.046 & 0.065 & -0.262 & 0.579 \\
\hline
\end{tabular}

Notes: ${ }^{a}$ Description of the variables: CASH represents the cash holdings in SBF120 French companies (= cash and cash equivalents /total assets), ACC indicates discretionary accruals (= (net income - operating cash flow)/total assets), DACC represents the binary variable 


\section{Mll Macrothink}

International Journal of Accounting and Financial Reporting

ISSN 2162-3082

2021, Vol. 11, No. 3

equal to 1 if $\mathrm{ACC}$ is negative, and 0 if $\mathrm{ACC}$ is positive. PFAD shows the percentage of female executives. SIZE represents the firm size (= logarithm of the total assets), and ROA indicates return on assets (=net income /total assets).

First, for the dependent variable, we note that the cash holding (CASH) varies between 0.001 and 1.960. Its average and its standard deviation are respectively 0.119 and 0.181 . We also note that the level of cash holdings varies among the companies of the sample.

Second, for the independent variable, the discretionary accruals (ACC) vary between 0.010 to 0.099 with an average of 0.043 and a standard deviation equal to 0.024 . We also note that the binary variable of discretionary accruals (DACC) varies between 0 and 1 . Its average and its standard deviation are respectively 0.856 and 0.351 .

Third, the moderating variable (PFAD) is on average 0.268 with a maximum of 0.54 and a minimum of 0 . Its standard deviation is 0.099 .

Furthermore, for control variables, we note that the firm size (SIZE) is between 2.022 and 6.898. Its average and standard deviation are respectively 4.04 and 0.684 . Return on assets (ROA) presents an average of 0.046 and a standard deviation of 0.065 . It varies between -0.262 and 0.579 .

\subsection{Correlation Between Explanatory Variables}

Table 3 summarizes the associations between the different variables. For the explanatory variables of the previously defined model, we note that the highest coefficient of correlation (0.169) lies between return on assets (SIZE) and the cash holdings (ACC).

Table 3. Correlation matrix between variables

\begin{tabular}{lrccccc}
\hline & CASH & ACC & DACC & PFADD & SIZE & ROA \\
\hline CASH & 1.000 & & & & & \\
ACC & 0.069 & 1.000 & & & & \\
DACC & -0.026 & 0.102 & 1.000 & & & \\
PFAD & 0.075 & 0.053 & -0.075 & 1.000 & & \\
SIZE & -0.160 & $(0.169)$ & 0.021 & 0.080 & 1.000 & \\
ROA & 0.119 & -0.091 & -0.167 & -0.034 & -0.393 & 1.000 \\
\hline
\end{tabular}

Notes:

${ }^{\mathrm{a}}$ See Table 2 for the description of variables.

$\mathrm{N}=500$ for all variables.

${ }^{\mathrm{b}}$ the highest correlation coefficient is expressed between the parenthesis.

\subsection{Econometric Regression}

It would be interesting to present the results of the econometric regression. These results were collected through the Stata software, while the attached data were gathered from several 
sources into an Excel file. The objective of this study is to confirm our theoretical developments based on these estimations.

\subsubsection{Presentation of Results}

The results of the estimation of different models are presented in the following table:

Table 4. Regression analysis

\begin{tabular}{llllllc}
\hline CASH & Coef. & Std. Err. & $\mathrm{Z}$ & $\mathrm{P}>[\mathrm{Z}]$ & \multicolumn{2}{c}{ [95\% conf. Interval] } \\
\hline ACC & -0.001 & -0.001 & -1.99 & $0.046^{* *}$ & -0.003 & -0.000 \\
DACC & -0.189 & 0.046 & -4.12 & $0.000^{* * *}$ & -0.279 & -0.099 \\
PFAD & 0.552 & 0.140 & 3.94 & $0.000^{* * *}$ & 0.827 & 0.278 \\
DACCACC & 0.001 & 0.001 & 1.83 & $0.092^{*}$ & -0.000 & 0.003 \\
DACCPFAD & 0.664 & 0.152 & 4.34 & $0.000^{* * *}$ & 0.364 & 0.964 \\
ACCPFAD & 0.008 & 0.004 & 1.97 & $0.049^{* *}$ & 0.000 & 0.017 \\
DACCACCPFAD & 0.008 & 0.004 & 1.83 & $0.067^{*}$ & 0.185 & 0.000 \\
SIZE & -0.046 & 0.020 & -2.27 & $0.023^{* * *}$ & -0.086 & -0.006 \\
ROA & 0.304 & 0.108 & 2.81 & $0.005^{* * *}$ & 0.091 & 0.517 \\
Cons & 0.446 & 0.095 & 4.70 & $0.000^{* * *}$ & 0.260 & 0.632 \\
\hline
\end{tabular}

${ }^{\text {a }}$ See Table 2 for the description of variables.

Number of observation $=500$

Adjusted $\mathrm{R}^{2}=0.047$, Chi2 $(\mathrm{p}$ value $)=0.000$

*significant at $10 \%$;* significant at $5 \%$; *** significant at $1 \%$

\section{Testing Hypothesis 1: The effect of accounting conservatism on cash holding}

Table 4 shows that the regression coefficient (DACC*ACC) of accounting conservatism is positive and statistically significant of (0.092). This is in line with Hypothesis 1 (H1) which stipulates that accounting conservatism has an effect on cash holdings.

The validity of this hypothesis is accepted by Watts (2003) who maintains that accounting conservatism practices can mitigate agency issues, provide incentives for efficient investment decisions, mitigate under-investment in capital rationing and limit over-investment by requiring managers to predict the occurrence of losses. Therefore, this contributes to mitigating the value destruction associated with cash holdings.

In what follows, we will try to prove whether the effect of the moderating variable (presence of female executives) moderates this relationship.

Test of Hypothesis 2: The effect of the presence of female executives on the relationship between accounting conservatism and cash holdings.

In this model, the regression test results show that the interaction variable (DACC*ACC*PFAD) has a positive effect equal to (0.067). This is in line with our second hypothesis (H2), according to which the presence of female executives strengthens the 


\section{Mll Macrothink}

International Journal of Accounting and Financial Reporting

ISSN 2162-3082

2021, Vol. 11, No. 3

relationship between accounting conservatism and cash-holding. This means that accounting conservatism has a significantly positive impact on cash holdings when there is a significant percentage of women on the board of directors. Therefore, this leads to a conservative approach that reduces aggression.

This can be explained by their stronger ethical disposition that has been observed in the accounting context, as they are commonly described as less repressive, less authoritarian, too insecure, more risk-averse, more caring and more ethical, which are all qualities that suggest a conservative frame of mind that is less likely to commit fraud (Vermeir and Kenhove, 2008; Cumming et al., 2014). This also has important accounting and economic implications (Schrand and Zechman, 2012; Prottas, 2013). Consequently, they prudently increase the need for cash reserves to protect against the risk of declining results, as indicated by Adhikari (2016), since women-led enterprises hold more liquidity for precautionary reasons.

As also indicated by Sanyum and Lihong (2015), who noted that female CEOs moderate the problem of over-investment related to available debt flows. As a result, this ethical work environment fosters honesty in financial reporting and practically promotes more conservative accounting (Francis et al. 2014; Huang and Kisgen, 2013; Simon et al. (2014), and this will lead to increased liquidity.

This could also be explained by the idea that female executives influence the dynamics of the administrative board, which would have a considerable impact on its decision and the results of businesses. This will also reinforce surveillance efforts that will consequently improve companies' strategic decisions (Adams and Ferreira 2009). This idea has already been introduced by Gul et al. (2011) who suggest that gender-mixed boards complement corporate governance and good management practice. For instance, strong ethical leadership is often linked to corporate profitability and performance (Luckerath Rovers, 2010; Evershed LLP, 2011; Rodriguez et al. 2012). This will be interpreted as an increase in cash holdings.

In addition, the analysis of the direct effect of the presence of female executives on cash holdings (CASH) shows that there is also a positive and statistically significant effect equal to (0.000). This can also be explained by the hypothesis of risk aversion. It increases the need for the provision of liquidity accumulations as a precaution in order to cope with an unpredictable decline in results and to hedge risks. This idea has already been introduced by $\mathrm{Xi}$ et al. (2019), who note that women-led enterprises hold more liquidity, which fosters the explanation based on precautionary savings. This result is also consistent with the majority of previous studies, namely Huang and Kisgen (2013); Faccio et al.(2016); Adhikari et al.(2016); Mateos de Cabo et al. (2012) and Zeng and Wang (2015), who predict that the risk is significantly lower for women, since they tend to avoid risky financial investment opportunities.

\section{Control Variables:}

According to the results of the regression tests, we note that there is a negative impact of the firm size (SIZE) on the level of cash holdings. This negative impact can be interpreted by the hypothesis of arbitrage where large businesses benefit from the economies of scale relating to 


\section{Macrothink}

International Journal of Accounting and Financial Reporting ISSN 2162-3082

the costs of cash holdings and the costs of external financing. The pecking order theory represents an index of informational irregularity, especially as large firms have an easier access to loans because they do not need to retain a significant amount of cash in order to finance their commitments.

However, the return on assets (ROA) has a positive and significant effect. This association can be explained by the fact that enterprises that achieve a high level of return therefore have a higher level of cash holdings.

\section{Conclusion}

This study contributes to deeply analyzing the behavior of companies in terms of treasury in relation to the concept of accounting conservatism. It also allows to interpret the moderating effect of the presence of female executives on this relationship based on an empirical study having a hypothetical-deductive approach and departing from panel data from 100 French companies listed in SBF 120 over the period 2011-2015.

The obtained results show that accounting conservatism has a positive effect on cash holding and that the presence of female executives is a factor strengthening this relationship. In other words, accounting conservatism has a positive and more significant effect on the cash holdings in the presence of a significant percentage of female executives because they adopt a more cautious approach than their male counterparts.

We explained these results mainly by a stronger ethical disposition in women observed in the accounting framework, as women are generally described as being less aggressive, less authoritarian, less self-confident, and therefore more averse to risk, more concerned and more ethical. All these characters suggest a conservative mindset (Cumming et al. 2014). Consequently, all these behaviors of women lead to an increase in the level of cash holdings as a precautionary measure to combat a potential decline in results and hedge against risks (Adhikari et al. 2018).

To conclude, we believe that this research would be more complete by including other governance variables such as administrative board independence, control block or other to better explain the relationship between accounting conservatism and cash holdings. It would be thus legitimate to establish a comparison with other countries that have different cultures, keeping the same variables.

\section{References}

Adams, R. B., \& Ferreira, D. (2009). Women in the boardroom and their impact on governance and performance. Journal of Financial Economics, 94(2), 291-309. https://doi.org/10.1016/j.jfineco.2008.10.007

Adams, R. B., \& Santos, J. A. C. (2006). Identifying the effect of managerial control on firm performance. Journal of Accounting and Economics, 4(1), 55-85. https://doi.org/10.1016/j.jacceco.2005.08.001 


\section{Mll Macrothink}

International Journal of Accounting and Financial Reporting ISSN 2162-3082 2021, Vol. 11, No. 3

Adhikari, B. K. (2018). Female executives and corporate cash holdings. Applied Economics Letters, 25(13), 958-963. https://doi.org/10.1080/13504851.2017.1388904

Adhikari, B. K., \& Agrawal, A. (2016). Does local religiosity matter for bank risk-taking?. Journal of Corporate Finance, 38, 272-293. https://doi.org/10.1016/j.jcorpfin.2016.01.009

Adjaoud, F., Zeghal, D., \& Andaleeb, S. (2007). The Effect of Board's Quality on Performance: a study of Canadian firms. Corporate Governance an International Review, 15(4), 623-625. https://doi.org/10.1111/j.1467-8683.2007.00592.x

Ahmed, A. S., Neel, M., \& Wang, O. (2013). Does Mandatory Adoption of IFRS improve Accounting Quality? Preliminary Evidence. Comptemporary Accounting Research, 30(4), 1344-1372. https://doi.org/10.1111/j.1911-3846.2012.01193.x

Ahmed, K., \& Henry, O. (2012). Accounting Conservatism and Voluntary Corporate Governance Mechanisms by Australian Firms. Accounting \& Finance, 52(3), 631-662. https://doi.org/10.1111/j.1467-629X.2011.00410.x

André, P., \& Filip, A. (2011). Accounting Conservatism in Europe and the Impact of Madatory IFRS Adoption: A Look at Legal Incentives, Corporate Govemance, Enforceemnt Prior Accounting Traditions and Tax Book Conformity. Financial Reporting ESSEC-KPMG. https://doi.org/10.2139/ssrn.1979748

Andres, P., Azofra, V., \& Lopez, F. (2005). Corporate boards in OECD countries: size, composition, functioning and effectiveness. Corporate Governance, 13(2), 197-210. https://doi.org/10.1111/j.1467-8683.2005.00418.x

Arfken, D. E., Bellar, S. L., \& Helms, M. M. (2004). The Ultimate Glass Ceiling Revisited: The Presence of Women on Corporate Boards. Journal of Business Ethics, 50, 177-186. https://doi.org/10.1023/B:BUSI.0000022125.95758.98

Bahagat, S., \& Black. (2001). The non-correlation between board independence and long term firm performance. Journal of Corporation Law, 27(2), 231-274.

Ball, R., \& Shivakumar, L. (2005). Earnings Quality in U. K. private firms: Comparative Loss Recognition Timeliness. Journal of Accounting and Economies, 39(1), 83-128. https://doi.org/10.1016/j.jacceco.2004.04.001

Ball, R., Robin, A., \& Sadka, G. (2008). Is financial reporting shaped by equity markets or by debt markets? An international study of timeliness and conservatism. Review of Accounting Studies, 13(2), 168-205. https://doi.org/10.1007/s11142-007-9064-x

Basu, S. (1997). The conservatism principle and the asymmetric timeliness of earnings. Journal of Accounting and Economics, 24(1), 3-37. https://doi.org/10.1016/S0165-4101(97)00014-1

Basu, S., Hwang, L., \& Jan, C. (2001). Auditor Conservatism and Quarterly Earnings. SSRN 2428862. https://doi.org/10.2139/ssrn.2428862

Bauer, R., Frijns, B., Otten, R., \& Tourani, A. (2008). The impact of corporate governance on corporate performance: evidence from Japan. Pacific-Basin Finance Journal, 16(3), 236-251. 


\section{Mll Macrothink}

International Journal of Accounting and Financial Reporting ISSN 2162-3082 2021, Vol. 11, No. 3

Biddle, G. C., \& Hilary, G. (2006). Accounting quality and firm-level capital investment. Accounting Review, 81(5), 963-982. https://doi.org/10.1016/j.pacfin.2007.05.001

Biddle, G. C., Hilary, G., \& Verdi, R. S. (2009). How does financial reporting quality relate to investment efficiency?. Journal of Accounting and Economics, 48(2), 112-131. https://doi.org/10.1016/j.jacceco.2009.09.001

Brealey, R., Myers, S. C., \& Allen, F. (2006). Corporate Finance (8th ed.). McGraw Hill, New York.

Brown, J. R., \&Petersen, B. C. (2011). Cash Holdings and R\&D Smoothing. Journal of Corporate Finance, 17(3), 694-709. https://doi.org/10.1016/j.jcorpfin.2010.01.003

Brown, M. E., \& Mitchell, M. S. (2010). Ethical and unethical leadership: Exploring new avenues for future research. Business Ethics Quarterly, 20(4), 583-616. https://doi.org/10.5840/beq201020439

Bruce, S., \& Halit, G. (2016). The Effects of Country and Firm-Level Governance on Cash Management. Journal of International Financial Markets Institutions and Money, 27(1), 65-90.

Bushman, R. M., \& Smith, A. J. (2001). Financial accounting information and corporate governance. Journal of Accounting and Economics, 32(1), 237-333. https://doi.org/10.1016/S0165-4101(01)00027-1

Bushman, R. M., Piotroski, J. D., \& Smith, A. J. (2011). Capital allocation and timely accounting recognition of economic losses. Journal of Business Finance and Accounting, 38(1), 1-33. https://doi.org/10.1111/j.1468-5957.2010.02231.x

Byrnes, J. P., Miller, D. C., \& Schafer, W. D. (1999). Gender differences in risk taking: A $\begin{array}{lllll}\text { meta-analysis. } & \text { Psychological } & \text { Bulletin, } & \text { 125, }\end{array}$ https://doi.org/10.1037/0033-2909.125.3.367

Callen, J., Segal, D., \& Hope, O. (2010). The pricing of conservative accounting and the measurement of conservatism at the firm-year level. Review of Accounting Studies, 15(1), 145-178. https://doi.org/10.1007/s11142-009-9087-6

Campbell, K., \& Minguez Vera, A. (2010). Female board appointments and firm valuation: Short and long-term effects. Journal of Management and Governance, 14(1), 37-59. https://doi.org/10.1007/s10997-009-9092-y

Campbell, K., \& Minguez-Vera, A. (2008). Gender diversity in the boardroom and firm financial performance. Journal of Business Ethics, 83(3), 435-451. https://doi.org/10.1007/s10551-007-9630-y

Chen, C., Li, Z., Su, X., \& Sun, Z. (2011). Rent-seeking incentives, corporate political connections, and the control structure of private firms: Chinese evidence. Journal of Corporate Finance, 17(2), 229-243. https://doi.org/10.1016/j.jcorpfin.2010.09.009

Costa, P., Terracciano, A., \& McCrae, R. R. (2001). Gender differences in personality traits across cultures: Robust and surprising findings. Journal of Personality and Social Psychology, 81(2), 322-331. https://doi.org/10.1037/0022-3514.81.2.322 


\section{М Macrothink}

International Journal of Accounting and Financial Reporting ISSN 2162-3082

Cullinan, C. P., Wang, F., Wang, P., \& Zhang, J. (2012). Ownership structure and accounting conservatism in China. Journal of International Accounting. Auditing and Taxation, 21(1), 1-16. https://doi.org/10.1016/j.intaccaudtax.2012.01.001

Cumming, D. J., Leung, T. K., \& Rui, O. M. (2014). Gender diversity and securities fraud. https://doi.org/10.2139/ssrn.2471081

Daske, H. (2006). Economic benefits of adopting IFRS or US-GAAP - Have the expected cost of equity capital really decreased?. Journal of Business Finance \& Accounting, 33(3), 329-373. https://doi.org/10.1111/j.1468-5957.2006.00611.x

Daske, H., Hail, L., Leuz, C., \& Verdi, R. (2008). Mandatory IFRS reporting around the world: Early evidence on the economic consequences. Journal of Accounting Research, 46(5), 1085-1142. https://doi.org/10.1111/j.1475-679X.2008.00306.x

Dechow, P., Weili, G., \& Schrand, C. (2010). Understanding earnings Quality: A Review of Proxies, their Determinants and their Consequences. Journal of Accounting and Economies, 50(2), 344-401. https://doi.org/10.1016/j.jacceco.2010.09.001

Dittmar, A., \& Mahrt-Smith, J. (2007). Corporate governance and the value of cash holdings. Journal of Financial Economics, 83(3), 599-634. https://doi.org/10.1016/j.jfineco.2005.12.006

Doyle, J., W. Ge., \& McVay, S. (2007). Determinants of weaknesses in internal control over financial reporting. Journal of Accounting and Economics, 44(1), 193-223. https://doi.org/10.1016/j.jacceco.2006.10.003

Durnev, A., \& Kim, E. H. (2005). To steal or not to steal: Firm attributes, Legal environment, and valuation. Journal of Finance, 60(3), 1461-1493. https://doi.org/10.1111/j.1540-6261.2005.00767.x

Eckel, C. C., \& Grossman, P. J. (2008). Forecasting risk attitudes: An experimental study using actual and forecast gamble choices. Journal of Economic Behavior \& Organization, 68(1), 1-17. https://doi.org/10.1016/j.jebo.2008.04.006

Evershed, L. L. P. (2011). The Eversheds board report: Measuring the impact of board composition on company performance. Publisher: London: Eversheds.

Faccio, M., Marchica, M. T., \& Roberto, M. (2016). CEO gender, corporate risk-taking, and the efficiency of capital allocation. Journal of Corporate Finance, 39, 193-209. https://doi.org/10.1016/j.jcorpfin.2016.02.008

Faulkender, M., \& Wang, R. (2006). Corporate financial policy and the value of cash. Journal of Finance, 61(4), 1957-1990. https://doi.org/10.1111/j.1540-6261.2006.00894.x

Francis, J. R., \& Martin, X. (2010). Acquisition profitability and timely loss recognition. Journal of Accounting and Economics, 49(1), 161-178. https://doi.org/10.1016/j.jacceco.2009.09.003

Francis, J. R., LaFond, R. Z., Olsson, P., \& Shipper, K. (2004). Costs of Equity and Earnings $\begin{array}{llll}\text { Attributes. The } & \text { Accounting } & \text { 79(4), } & \text { 967-1010. }\end{array}$ 
https://doi.org/10.2308/accr.2004.79.4.967

Francis, W., Hasan, I., \& Qiang, W. (2013). The impact of CFO gender on bank loan contracting. Journal of Accounting, Auditing \& Finance, 28, 53-78. https://doi.org/10.1177/0148558X12452399

Francis, W., Hasan, I., Park, J. C., \& Qiang, W. (2014). Gender differences in financial reporting decision making: Evidence from accounting conservatism. Contemporary Accounting Research, 32(3), 1285-1318. https://doi.org/10.1111/1911-3846.12098

Francoeur, C., Labelle, R., \& Sinclair-Desgagne, B. (2008). Gender diversity in corporate governance and top management. Journal of Business Ethics, 81(1), 83-95. https://doi.org/10.1007/s10551-007-9482-5

Garcia Lara, J. M., Rueda Torres., J. A., Vazquez, P., \& Eira, V. (2008). Conservatism of Earnings Reported under International Accounting Standards: a Comparative Study. Revista Espanola de Financiacion y Contabilidad, 37(138), 197-210. https://doi.org/10.1080/02102412.2008.10779642

Garcia Lara, J. M., Garcia Osma, B., \& Pena1va, F. (2009). Accounting Conservatism and Corporate Governance. Review of Accounting Studies, 14(1), 161-201. https://doi.org/10.1007/s11142-007-9060-1

Garcia Lara, J. M., Osma, B. G., \& Penalva, F. (2016). Accounting conservatism and firm investment efficiency. Journal of Accounting and Economics, 61(1), 221-238. https://doi.org/10.1016/j.jacceco.2015.07.003

Givoly, D., \& Hayn, C. (2000). The changing time-series properties of earnings, cash flows and accruals: Has financial reporting become more conservative?. Journal of Accounting and Economics, 29(3), 287-320. https://doi.org/10.1016/S0165-4101(00)00024-0

Groebner, D. F., Shannon, P. W., Fry, P. C., \& Smith, K. D. (2008). Business statistics: a decision-making approach (7th ed.). Prentice Hall, New Jersey, p. 696.

Gul, F. A., Srinidhi, B., \& Ng, A. C. (2011). Does board gender diversity improve the informativeness of stock prices?. Journal of Accounting and Economics, 35(1), 314-338. https://doi.org/10.1016/j.jacceco.2011.01.005

Habib, A., \& Hossain, M. (2013). Accounting conservatism, environmental uncertainty and the capital structure. Corporate Ownership and Control, 11(1), 123-135. https://doi.org/10.22495/cocv11i1c1art1

Holthausen, R., \& Watts, R. (2001). The relevance of the value-relevance literature for financial accounting standard setting. Journal of Accounting and Economies, 31(1), 3-75. https://doi.org/10.1016/S0165-4101(01)00029-5

Hu, J., Li, A., \& Zhang, F. (2014). Does accounting conservatism improve the corporate information environment?. Journal of International Accounting, Auditing and Taxation, 23(1), 32-43. https://doi.org/10.1016/j.intaccaudtax.2014.02.003

Huang, J., \& Kisgen, D. J. (2013). Gender and corporate finance: Are male executives overconfident relative to female executives. Journal of Financial Economics, 108(3), 822-839. https://doi.org/10.1016/j.jfineco.2012.12.005

Huijgen, C., \& Lubberink, M. (2005). Earnings Conservatism, Litigation, and Contracting: 


\section{Macrothink}

International Journal of Accounting and Financial Reporting ISSN 2162-3082 2021, Vol. 11, No. 3

The Case of Cross-Listed Firms. Journal of Business finance \& Accounting, 32(7), 1275-1310. https://doi.org/10.1111/j.0306-686X.2005.00629.x

Hung, M., \& Subramanyam, K. R. (2007). Financial Statement Effects of Adopting International Accounting Standards: the Case of Germany. Review of Accounting Studies, 12(4), 623-657. https://doi.org/10.1007/s11142-007-9049-9

Hunter, S. (2012). Ethical leadership and identity: What did we learn and where do we go from here?. Journal of Business Ethics, 107(1), 79-87. https://doi.org/10.1007/s10551-012-1301-y

Ibrahim, N., \& Angelidis, J. (2009). The relative importance of ethics as a selection criterion for entry-level public accountants: Does gender make a difference?. Journal of Business Ethics, 85, 49-58. https://doi.org/10.1007/s10551-008-9946-2

Jensen, M., \& Meckling, W. (1976). Theory of the Firm: Managerial Behavior, Agency Costs and Capital Structure. Journal of Financial Economics, 3(4), 305-360. https://doi.org/10.1016/0304-405X(76)90026-X

Jensen, M. (1986). Agency costs of free cash flow, corporate finance, and takeovers. American Economic Review, 76(2), 323-329.

Jianakoplos, N. A., \& Bernasek, A. (2007). Are women more risk averse?. Economic Inquiry, 36(4), 620-630. https://doi.org/10.1111/j.1465-7295.1998.tb01740.x

Jones, J. (1991). Earnings management during import relief investigations. Journal of Accounting Research, 29(2), 193-228. https://doi.org/10.2307/2491047

Kaytmaz Balsari, C., Ozkan, S., \& Durak, M. G. (2010). Earnings Conservatism in the Preand Post- IFRS Adoption Periods in Turkey: Panel Data Evidence on the Firm Specific Factors. Journal of Accounting and Management Information Systems, 9(3), 403-421.

Keynes, J. M. (1936). The general theory of employment interest and money. London: Macmillan.

Khan, M., \& Watts, R. (2009). Estimation and empirical properties of a firm-year measure of conservatism. Journal of Accounting and Economics, 48(2), 132-150. https://doi.org/10.1016/j.jacceco.2009.08.002

Klein, A. (2002). Audit committee, board of director characteristics, and earnings management. Journal of Accounting and Economics, 33(3), 375-400. https://doi.org/10.1016/S0165-4101(02)00059-9

Kotiranta, A., Kovalainen, A., \& Rouvinen, P. (2007). Female leadership and firm profitability. EVA Analysis, 3.

Krishnan, G. V., \& Parsons, L. M. (2008). Getting to the bottom line: An exploration of gender and earnings quality. Journal of Business Ethics, 78, 65-76. https://doi.org/10.1007/s10551-006-9314-z

Kwon, S., Yin, J., \& Han, J. (2006). The Effect of Differentiae Accounting Conservatism on the Overvaluation of High-Tech relative to Low-Tech firms. Review of Quantitative Finance and Accounting, 27(2), 143-173. https://doi.org/10.1007/s11156-006-8794-3

La Porta, R., Lopez-de-Silanes, F., Shleifer, A., \& Vishny, R. (2000). Agency problems and 
dividend policies around the world. Journal of Finance, 55(1), 1-33. https://doi.org/10.1111/0022-1082.00199

Lafond, R., \& Roychowdhury, S. (2008). Managerial ownership and accounting conservatism. Journal of Accounting Research, 46(1), 101-135. https://doi.org/10.1111/j.1475-679X.2008.00268.x

Leuz, C., \& Verrecchia, R. E. (2000). The economic consequences of increased disclosure. Journal of Accounting Research, 38, 91-124. https://doi.org/10.2307/2672910

Leventis, S., Dimitropoulos, P., \& Owusu-Ansah, S. (2013). corporate governance and accounting conservatism: Evidence from the banking industry. Corporate Governance: An International Review, 21(3), 264-286. https://doi.org/10.1111/corg.12015

Levin, I. P., Snyder, M. A., \& Chapman, D. P. (1988). The interaction of experiential and situational factors and gender in a simulated risky decision-making task. The Journal of Psychology, 122(2), 173-181. https://doi.org/10.1080/00223980.1988.9712703

$\mathrm{Li}, \mathrm{S}$. (2010). Does mandatory adoption of international financial reporting standards in the European Union reduce the cost of equity capital?. Accounting Review, 85(2), 607-636. https://doi.org/10.2308/accr.2010.85.2.607

Luckerath-Rovers, M. (2010). Women on boards and firm performance. Journal of Management and Governance, 17(2), 491-509. https://doi.org/10.1007/s10997-011-9186-1

Mahadeo, J. D., Soobaroyent, T., \& Hanuman, V. (2012). Board Composition and Financial Performance: Uncovering the Effects of Diversity in an Emerging Economy. Journal of Business Ethics, 105(3), 375-388. https://doi.org/10.1007/s10551-011-0973-z

Mateos de Cabo, R., Gimeno, R., \& Nieto, M. J. (2012). Gender diversity on European banks' boards of directors. Journal of Business Ethics, 109(2), 145-162. https://doi.org/10.1007/s10551-011-1112-6

Morris, J. (1983). The role of cash balances in firm valuation. Journal of Financial and Quantitative Analysis, 18(4), 533-545. https://doi.org/10.2307/2330946

Neubert, M. J., Carlson, D. S., Kacmar, K. M., Roberts, J. A., \& Chonko, L. B. (2009). The virtuous influence of ethical leadership behavior: Evidence from the field. Journal of Business Ethics, 90, p57-170. https://doi.org/10.1007/s10551-009-0037-9

Niederle, M., \& Vesterlund, L. (2007). Do women shy away from competition? Do men compete too much?. The Quarterly Journal of Economics, 122(3), 1067-1102. https://doi.org/10.1162/qjec.122.3.1067

Ogundipe, L. O., Ogundipe, S. E., \& Ajao, S. K. (2012). Cash Holding and Firm Characteristics: Evidence from Nigerian Emerging Market. Journal of Business, Economics \& Finance, 1(2), 45-58.

O'Laughlin, E., \& Brubaker, B. (1998). Use of landmarks in cognitive mapping: Gender differences in self report versus performance. Personality and Individual Differences, 24(5), 595-601. https://doi.org/10.1016/S0191-8869(97)00237-7 


\section{Macrothink}

International Journal of Accounting and Financial Reporting ISSN 2162-3082

Opler, T., Pinkowitz, L., Stulz, R., \& Williamson, R. (1999). The determinants and implications of cash holdings. Journal of Financial Economics, 5(1), 3-46.

Piot, C., Dumontier, P., \& Janin, R. (2011). IFRS Consequences on Accounting Conservatism within Europe: the role of big 4 auditors. University of Grenoble and CERAG-CNRS. Grenoble. https://doi.org/10.2139/ssrn.1754504

Powell, M., \& Ansic, D. (1997). Gender differences in risk behaviour in financial decision-making: An experimental analysis. Journal of Economic Psychology, 18(6), 605-628. https://doi.org/10.1016/S0167-4870(97)00026-3

Prottas, D. (2013). Relationships among employee perception of their manager's behavioral integrity, moral distress, and employee attitudes and well-being. Journal of Business Ethics, 113(1), 51-60. https://doi.org/10.1007/s10551-012-1280-z

Raonic, I., McLeay, S., \&Asimakopoulos, I. (2004). The Timeliness of Income Recognition by European Compagnies: An Analysis of institutional and Market Complexity. Journal of Business Finance \& Accounting, 31(1), 115-148. https://doi.org/10.1111/j.0306-686X.2004.00004.x

Rodriguez-Dominguez, L., Garcia-Sanchez, I. M., \& Gallego-Alvarez, I. (2012). Explanatory factors of the relationship between gender diversity and corporate performance. European Journal of Law and Economics, 33(3), 603-620. https://doi.org/10.1007/s10657-010-9144-4

Schrand, C. M., \& Zechman, S. L. C. (2012). Executive overconfidence and the slippery slope to financial misreporting. Journal of Accounting and Economics, 53(1), 311-329. https://doi.org/10.1016/j.jacceco.2011.09.001

Sharma, S., Durand, R. M., \& Gur-Arie, O. (1981). Identification and Analysis of Moderator Variables. Journal of marketing Research, 18(3), 291-300. https://doi.org/10.1177/002224378101800303

Simon, S. M. H., Li, A. Y., Tam, K., \& Zhang, F. (2014). CEO Gender, Ethical Leadership, and Accounting Conservatism. Journal of Business Ethics, 127(2), 351-370. https://doi.org/10.1007/s10551-013-2044-0

Sivakumar, K., \& Waymire, G. (2003). Enforceable Accounting Ru les and Income Measurement by early 20th Century Railroads. Journal of Accounting Research, 41(2), 397-432. https://doi.org/10.1111/1475-679X.00110

Skinner, D. (1993). The investment opportunity set and accounting procedure choice: Preliminary evidence. Journal of Accounting Economics, 16(4), 407-445. https://doi.org/10.1016/0165-4101(93)90034-D

Tahir, M. S., \& Alifiah, M. N. (2015). Corporate Cash Holding Behavior and Financial Environment: A Critical Review. International Journal of Economics and Financial Issues, 5(1), 277-280.

Tate, G., \& Yang, L. (2015). Female leadership and gender equity: Evidence from plant $\begin{array}{lllll}\text { closure. Journal of Financial } & \text { Economics, } & 117(1),\end{array}$ https://doi.org/10.1016/j.jfineco.2014.01.004 


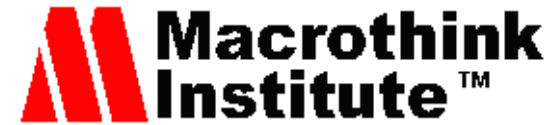

International Journal of Accounting and Financial Reporting ISSN 2162-3082

Vermeir, I., \& Kenhove, P. (2008). Gender Differences in Double Standards. Journal of Business Ethics, 81(2), 281-295. https://doi.org/10.1007/s10551-007-9494-1

Wagner, J. (2007). What a difference a Y makes: Female and male nascent entrepreneurs in Germany. Small Business Economics, 28(1), 1-21. https://doi.org/10.1007/s11187-005-0259-x

Watts, R. L. (2003). Conservatism in accounting part I: explanations and implications. Simon School of Business. Accounting Horizons, 17(1), 207-221. https://doi.org/10.2308/acch.2003.17.3.207

Xi, X., Li, W., Li, Y., \& Liu, X. (2019). Female CEO and corporate cash holdings: Precautionary motive or agency motive?. International Review of Economics and Finance, 63(C), 434-454. https://doi.org/10.1016/j.iref.2019.05.006

Zarai, M., \& Abderrahim, M. (2009). Accounting conservatism and cost of debt: study on a sample of Canadian companies. Publisher: The Summit Group, 6(1).

Zeljko, R., \& Nemanja, S. (2017). Analysis of the determinants of corporate cash holdings: Examples from companies in Serbia. The European Journal of Applied Economics, 14(1), 13-23. https://doi.org/10.5937/ejae14-13574

Zeng, S., \& Wang, L. (2015). CEO gender and corporate cash holdings. Are female CEOs more conservative?. Journal of Accounting and Economics, 22(4), 449-474. https://doi.org/10.1080/16081625.2014.1003568

Zeng, S., \& Wang, L. (2015). CEO gender and corporate cash holdings. Are female CEOs more conservative?. Asia-Pacific Journal of Accounting \& Economics, 22(4), 449-474. https://doi.org/10.1080/16081625.2014.1003568

\section{Copyright Disclaimer}

Copyright for this article is retained by the author(s), with first publication rights granted to the journal.

This is an open-access article distributed under the terms and conditions of the Creative Commons Attribution license (http://creativecommons.org/licenses/by/4.0/) 